\title{
Evidence that halogenated furanones from Delisea pulchra inhibit acylated homoserine lactone (AHL)-mediated gene expression by displacing the AHL signal from its receptor protein
}

\author{
Michael Manefield, ${ }^{1}$ Rocky de Nys, ${ }^{2,3}$ Naresh Kumar, ${ }^{4}$ Roger Read, ${ }^{4}$ \\ Michael Givskov, ${ }^{5}$ Peter Steinberg ${ }^{2,3}$ and Staffan Kjelleberg ${ }^{1,3}$
}

\author{
Author for correspondence: Staffan Kjelleberg. Tel: +61293852102 . Fax: +61293851591 \\ e-mail: S.Kjelleberg@unsw.edu.au
}
1,2,3,4 School of Microbiology and Immunology', School of Biological Sciences ${ }^{2}$, Centre for Marine Biofouling and Bio-Innovation ${ }^{3}$ and School of Chemistry4, University of New South Wales, Sydney, Australia
5 Department of Microbiology, Technical University of Denmark, Lyngby, Denmark

\begin{abstract}
Acylated homoserine lactone (AHL)-mediated gene expression controls phenotypes involved in colonization, often specifically of higher organisms, in both marine and terrestrial environments. The marine red alga Delisea pulchra produces halogenated furanones which resemble AHLs structurally and show inhibitory activity at ecologically realistic concentrations in AHL bioassays. Evidence is presented that halogenated furanones displace tritiated OHHL [N-3(oxohexanoyl)-L-homoserine lactone] from Escherichia coli cells overproducing LuxR with potencies corresponding to their respective inhibitory activities in an AHL-regulated bioluminescence assay, indicating that this is the mechanism by which furanones inhibit AHL-dependent phenotypes. Alternative mechanisms for this phenomenon are also addressed. General metabolic disruption was assessed with two-dimensional PAGE, revealing limited nonAHL-related effects. A direct chemical interaction between the algal compounds and AHLs, as monitored by ' 1 H NMR spectroscopy, was shown not to occur in vitro. These results support the contention that furanones, at the concentrations produced by the alga, can control bacterial colonization of surfaces by specifically interfering with AHL-mediated gene expression at the level of the LuxR protein.
\end{abstract}

Keywords: quorum sensing, AHL, acylated homoserine lactone, Delisea pulchra, halogenated furanones

\section{INTRODUCTION}

Acylated homoserine lactone (AHL)-mediated gene transcription controls a variety of bacterial phenotypes (for reviews see Fuqua et al., 1996; and Swift et al., 1996). The expression of bioluminescence in Vibrio fischeri is the most extensively studied example (Sitnikov et al., 1995). Two genes constitute the primary level of regulatory contol involved in the expression of this phenotype. One encodes an AHL synthase protein, known as a LuxI homologue. The other encodes a regulatory protein which alters transcriptional promoter activity of nominated genes in the presence of the AHL

Abbreviations : 2-D, two-dimensional; $A H L$, acylated homoserine lactone; OHHL, $\mathrm{N}$-3-(oxohexanoyl)-L-homoserine lactone. signal molecule and is known as a LuxR homologue. For example, in $V$. fischeri LuxI synthesizes N-3(oxohexanoyl)-L-homoserine lactone (OHHL) which binds to LuxR, activating transcription of genes encoding the luminescent phenotype (luxCDABEG). AHLs comprise the homoserine lactone ring with any one of a variety of modified acyl chains. At a secondary level of regulation other factors, including GroESL (Adar \& Ulitzur, 1993), cAMP and cAMP receptor protein (Dunlap, 1989), the traM gene product (Fuqua et al., 1995), opines (Fuqua \& Winans, 1994), RpoS and HNS (Ulitzur et al., 1997) influence expression of AHLdependent phenotypes.

AHL-regulated phenotypes often facilitate bacterial colonization of eukaryotes. Examples include elastase production by Pseudomonas aeruginosa in lung 
infections of cystic fibrosis patients (Pearson et al., 1997) and exoenzyme production by Erwinia carotovora in the maceration of economically important crops (Pirhonen et al., 1993). For instances where these bacterial activities are deleterious to the host, it is likely that higher organisms may have evolved a means of defending themselves from AHL-mediated colonization. Such an evolutionary response has been suggested to have occurred in the red marine alga Delisea pulchra (Kjelleberg et al., 1997).

D. pulchra, endemic to the south-eastern coast of Australia, produces a range of halogenated enones and furanones, some of which have strong inhibitory activity against fouling organisms and herbivores (de Nys et al., 1995; Steinberg \& van Altena, 1992; R. de Nys and others, unpublished). Additionally, furanones have specific effects on colonization phenotypes of marine bacteria at concentrations found on the surface of the alga (Maximilien et al., 1998). Swarming motility of marine isolates known to produce metabolites active in AHL bioassays (Maximilien, 1996) is one such phenotype. Swarming has been shown to be an AHLdependent behaviour in Serratia liquefaciens (Eberl et al., 1996). The above-mentioned algal metabolites structurally resemble AHLs, and thus we hypothesized that D. pulchra defends itself against extensive bacterial colonization by using halogenated furanones as antagonists of AHL-mediated gene expression. This hypothesis was supported by the inhibition of two AHLdependent phenotypes (swarming and bioluminescence) by two furanones from $D$. pulchra, with no effect on non-AHL-regulated phenotypes such as swimming motility, production of flagella, constitutively expressed bioluminescence and growth (Givskov et al., 1996). Furthermore, because furanones inhibited artificially stimulated AHL-dependent luminescence in the absence of LuxI, we hypothesized that the site of action was on the LuxR protein.

However, direct evidence that halogenated furanones interfere with the interaction between AHLs and the putative binding site of a LuxR homologue remains to be obtained. In this study we used $\left[{ }^{3} \mathrm{H}\right] \mathrm{OHHL}$ and a LuxR overexpression vector to confirm that halogenated furanones displace the bacterial signal from the LuxRbinding site with potencies corresponding to their respective inhibitory activities in an AHL-regulated bioluminescence assay. Components of the $V$. fischeri AHL system were considered most appropriate for use in this investigation given that their function is well characterized and that they are of marine origin (Hanzelka \& Greenberg, 1995). Two-dimensional (2-D) PAGE was also employed to assess whether the effect of halogenated furanones on AHL-mediated swarming and bioluminescence can be explained by a subtle metabolic disruption of bacterial cell function. Additionally, the possibility that the algal compounds act via a direct chemical interaction with the bacterial AHL signal was addressed by ${ }^{1} \mathrm{H}$ NMR spectroscopy and TLC. Our results substantiate the hypothesis that halogenated furanones produced by the eukaryote $D$. pulchra act on bacteria by displacing AHLs from their cognate LuxRlike regulatory proteins.

\section{METHODS}

Bacterial strains and plasmids. The bioluminescent monitor system consisted of Escherichia coli MT102 harbouring pSB403. pSB403 consists of the V. fischeri luxR and the luxI promoter region cloned from pSB237 (Bainton et al., 1992) transcriptionally fused to a promoterless $\operatorname{lu} x C D A B E$ cassette derived from Xenorhabdus luminescens (Winson et al., 1998). It also encodes tetracycline resistance $\left(20 \mu \mathrm{g} \mathrm{ml}^{-1}\right)$. When present in $E$. coli MT102, pSB403 cannot produce OHHL but can respond to its exogenous addition with a resultant bioluminescent phenotype. The LuxR overexpression system consists of E. coli XL-1 Blue harbouring pHK724 and pGroESL (Hanzelka \& Greenberg, 1995). pHK724 encodes the $p$ tac-controlled $l u x R$ gene from $V$. fischeri and ampicillin resistance $\left(50 \mu \mathrm{g} \mathrm{ml}^{-1}\right)$. pGroESL encodes plac-controlled groESL genes and chloramphenicol resistance $\left(25 \mu \mathrm{g} \mathrm{ml}^{-1}\right)$. All strains were propagated on Luria-Bertani (LB) media (Maniatis et al., 1982) with appropriate antibiotics for plasmid maintenance, unless otherwise specified.

Extraction of natural furanones. Furanones were extracted from D. pulchra according to protocols established by de Nys et al. (1993). Algal tissue was frozen, freeze-dried, extracted with dichloromethane and reduced in vacuo. Pure compounds were isolated from this crude extract by vacuum liquid chromatography and HPLC, and identified by ${ }^{1} \mathrm{H}$ and ${ }^{13} \mathrm{C}$ NMR spectroscopy (de Nys et al., 1993). Furanones were dissolved in ethanol for use in assays.

Synthesis of OHHL, $\left[{ }^{3} \mathrm{H}\right] \mathrm{OHHL}$ and compound 8. Synthetic OHHL was prepared according to the method of Eberhard et al. (1986). OHHL was dissolved in ethyl acetate for use in assays. $\left[{ }^{3} \mathrm{H}\right] \mathrm{OHHL}$ was prepared by an improved synthesis protocol (W. Lao, M. A. Long, N. Kumar \& R. W. Read, unpublished) based on the method of Kaplan et al. (1985). Compound 8 was prepared according to protocols established by Manny et al. (1997).

Bioluminescence assay and growth. Bioluminescence was quantified as relative light units on a Wallac 1450 Microbeta Plus liquid scintillation counter. OHHL and furanones were added to dilute $10 \mathrm{ml}$ cultures $\left(\mathrm{OD}_{600}<0.005\right)$ and the luminescence response of $100 \mu \mathrm{l}$ samples in triplicate was measured after $4 \mathrm{~h}$ incubation at $30^{\circ} \mathrm{C}$. Concentration ranges between $10 \mathrm{nM}$ and $100 \mathrm{nM}$ OHHL and up to $100 \mu \mathrm{M}$ of different furanones (compounds 1, 2, 3, 4, 5 and 8) were employed. Appropriate concentrations of the ethanol solvent were incorporated into control treatments.

Growth was monitored by following the $\mathrm{OD}_{600}$ of $10 \mathrm{ml}$ cultures in appropriate media from lag-, through exponentialinto stationary-phase growth at $30^{\circ} \mathrm{C}$. Growth measurements were performed in triplicate.

$\left[{ }^{3} \mathrm{H}\right] \mathrm{OHHL}$ binding and displacement. Binding and displacement protocols closely follow that of Hanzelka \& Greenberg (1995). E. coli XL-1 Blue(pHK724, pGroESL) and E. coli XL1 Blue(pGroESL) cultures were grown from $\mathrm{OD}_{600} 0 \cdot 01$ to 0.30 with shaking at $30^{\circ} \mathrm{C}$ in the presence of $1 \mathrm{mM}$ IPTG to stimulate the plac and $p$ tac promoters. At $\mathrm{OD}_{600} 0 \cdot 3,0 \cdot 5 \mu \mathrm{M}$ $\left[{ }^{3} \mathrm{H}\right] \mathrm{OHHL}$ with or without $10-100 \mu \mathrm{M}$ furanone (compound 2,4 or 8 ) or $0.5-5 \cdot 0 \mu \mathrm{M}$ OHHL was added to $1 \mathrm{ml}$ aliquots of both cultures in triplicate. Cultures were incubated at room temperature with shaking for a further $10 \mathrm{~min}$. Cells were centrifuged at $16000 \mathrm{~g}$ for $4 \mathrm{~min}$ at $4{ }^{\circ} \mathrm{C}$. The cell pellets were 
washed twice with $500 \mu \mathrm{LB}$ medium and finally resuspended in $100 \mu \mathrm{l}$ scintillation fluid. Radioactivity of samples was quantified on a Wallac 1450 Microbeta Plus liquid scintillation counter.

2-D PAGE. E. coli MT102(pSB403) was incubated in Difco minimal salts medium (without dextrose) plus $0 \cdot 2 \%$ glucose and $0.1 \%$ Casamino acids with shaking at $30^{\circ} \mathrm{C}$. At $\mathrm{OD}_{600}$ 0.03 the culture was divided into two vessels, one of which was treated with $0.5 \mu \mathrm{M} \mathrm{OHHL}$, the other with ethyl acetate as a control, and incubation continued. At $\mathrm{OD}_{600} 0.2$ the OHHLtreated culture was again divided into two, one half of which was treated with $50 \mu \mathrm{M}$ compound 4 and the other half with ethanol as a control. Incubation was continued for $30 \mathrm{~min}$. Three $0.5 \mathrm{ml}$ aliquots of each culture were transferred to $25 \mathrm{ml}$ glass flasks and treated with $\left[{ }^{35} \mathrm{~S}\right]$ methionine for $10 \mathrm{~min}$ with shaking at room temperature. Incorporation was stopped by chasing with $50 \mathrm{mM}$ unlabelled methionine for $4 \mathrm{~min}$. Cultures were centrifuged at $20000 \mathrm{~g}$ for $20 \mathrm{~min}$ at $4{ }^{\circ} \mathrm{C}$ and pellets frozen at $-75^{\circ} \mathrm{C}$. Proteins were extracted from cell pellets and resolved according to their charge and mass as described by O'Farrell (1975). The IEF dimension contained $4 \cdot 1 \%(\mathrm{w} / \mathrm{v})$ polyacrylamide and $6.25 \%$ ampholytes $(\mathrm{pH} 4-8$, Millipore). The second dimension was an $11.5 \%$ SDS-polyacrylamide gel. All conditions were according to Millipore specifications. Autoradiograms were prepared by $10 \mathrm{~d}$ exposure to Fuji RX film. Analysis was performed with the Bioimage 2-D analyser. Triplicate samples were resolved for each treatment on at least two separate occasions. Putative identity of spots was found by manually assessing the gene-protein database of E. coli K12 (VanBogelen et al., 1996).

In vitro reaction of $\mathrm{OHHL}$ and compound 4 . Solutions of OHHL $\left(9.3 \mathrm{mg}, 4.4 \times 10^{-5} \mathrm{~mol}\right)$ and 4-bromo-5-(bromomethylene)-3-(1-hydroxybutyl)-2(5H)-furanone (compound 4) $\left(14.2 \mathrm{mg}, 4.4 \times 10^{-5} \mathrm{~mol}\right.$ ) in $0.5 \mathrm{ml} \mathrm{CDCl}_{3}$ (non-polar medium) or $0.5 \mathrm{ml} \mathrm{d}_{6}$-DMSO (polar medium) were kept at room temperature, in the presence or absence of $1 \mathrm{ml}$ stationary-phase E. coli MT102(pSB403) culture (from which the compounds were extracted with ethyl acetate) and monitored by $300 \mathrm{~Hz}{ }^{1} \mathrm{H}$ NMR spectroscopy and normalphase silica gel TLC (eluents employed were either dichloromethane or $1 \%$ methanol in dichloromethane) over a $48 \mathrm{~h}$ period.

\section{RESULTS}

\section{Selecting a halogenated furanone for investigation}

D. pulchra produces more than 20 halogenated furanones (de Nys et al., 1993). To identify which furanone would constitute the most effective antagonist of the AHL system for use in the following investigation, we compared the activity of these naturally produced compounds and a number of synthetic analogues against the bioluminescent monitor strain E. coli MT102(pSB403). Of the molecules tested, compounds 3, 5 and 4 (Fig. 1) exhibited the greatest activity and were thus employed in this study. Compound 8 (Fig. 1), a synthetic halogenated furanone, was included as an example of a molecule with relatively weak activity. Compounds 1 and 2, which have been employed predominantly in previous studies, were also included (Givskov et al., 1996; Gram et al., 1996). Compounds $1-5$ are the most abundant furanones produced by the alga (de Nys et al., 1993).<smiles>[R]C([R3])=C1OC(=O)C([C@@H]([R3])CCC)=C1[R2]</smiles>

$\begin{array}{llcccc} & & \mathrm{R} 1 & \mathrm{R2} & \mathrm{R3} & \mathrm{R4} \\ \text { compound } & 1 & \mathrm{H} & \mathrm{Br} & \mathrm{Br} & \mathrm{Br} \\ \text { compound } & 2 & \mathrm{H} & \mathrm{Br} & \mathrm{H} & \mathrm{Br} \\ \text { compound } & 3 & \mathrm{OAc} & \mathrm{Br} & \mathrm{H} & \mathrm{Br} \\ \text { compound } & 4 & \mathrm{OH} & \mathrm{Br} & \mathrm{H} & \mathrm{Br} \\ \text { compound } & 5 & \mathrm{OAc} & \mathrm{Br} & \mathrm{H} & \mathrm{I} \\ \text { compound } & 8 & \mathrm{H} & \mathrm{H} & \mathrm{Br} & \mathrm{Br}\end{array}$

Fig. 1. Structural variations of five halogenated furanones produced by the benthic marine macroalga $D$. pulchra (compounds 1-5). Compound 8 was produced synthetically.

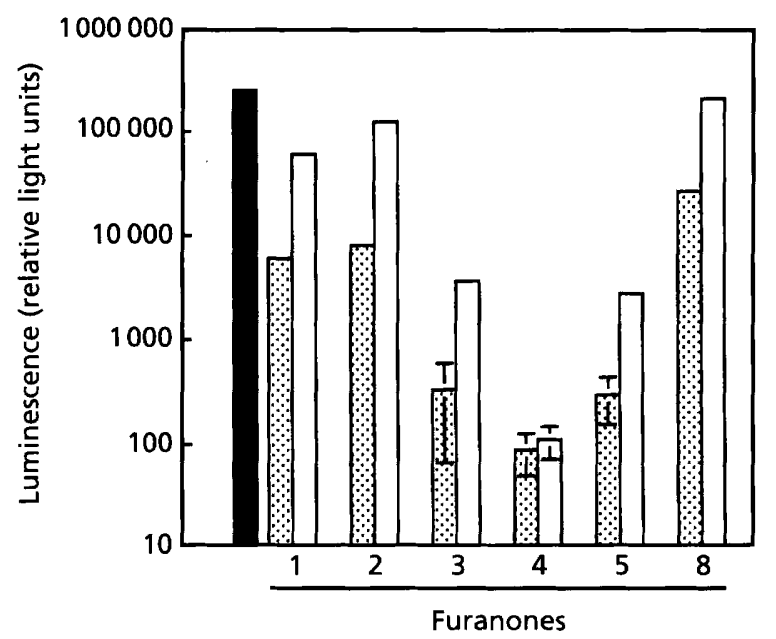

Fig. 2. Inhibitory effect of six halogenated furanones (compounds 1, 2, 3, 4, 5 and 8) at a concentration of $100 \mu \mathrm{M}$ ( $50 \mu \mathrm{M}$ for compound 4) on bioluminescence from OHHLstimulated E. coli(pSB403) (spotted bars). Partial relief of inhibition is shown as a result of increasing the concentration of $\mathrm{OHHL}$ from $10 \mathrm{nM}$ (spotted bars) to $100 \mathrm{nM}$ (white bars). Luminescence output from cultures treated with either $10 \mathrm{nM}$ or $100 \mathrm{nM}$ OHHL alone was identical (black bar). The experiment was performed in triplicate and error bars represent standard deviation.

Fig. 2 shows inhibition of the bioluminescent phenotype by compounds $1,2,3,4,5$ and 8 . None of the compounds had an effect on growth of E. coli(pSB403) at the concentrations tested (data not shown). Each furanone displayed a different potency, with compound 4 eliciting the largest response followed by compound 5, com- 


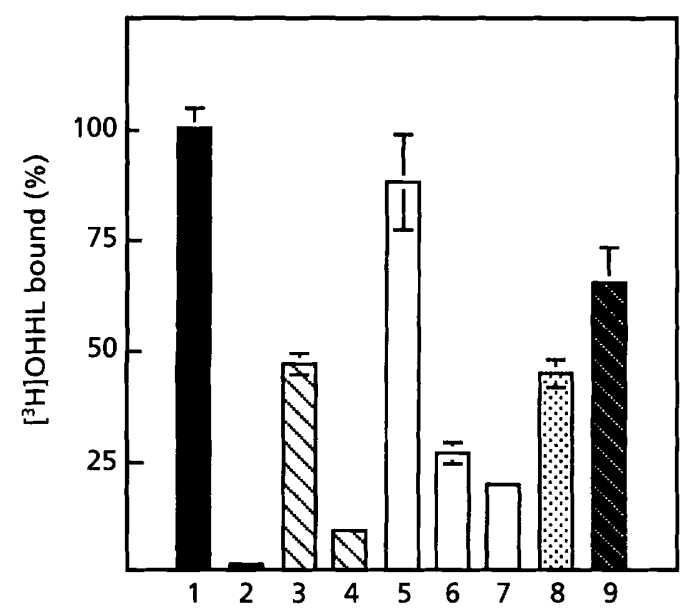

Fig. 3. In vivo displacement of $\left[{ }^{3} \mathrm{H}\right] \mathrm{OHHL}(0.5 \mu \mathrm{M})$ from $E$. coli(pHK724, pGroESL) cells overproducing LuxR. Bars represent radioactive signal bound in $E$. coli(pHK724, pGroESL) cultures treated with: (1) $0.5 \mu \mathrm{M}\left[{ }^{3} \mathrm{H}\right] \mathrm{OHHL}$ alone; or (3-9) $0.5 \mu \mathrm{M}$ $\left[{ }^{3} \mathrm{H}\right] \mathrm{OHHL}$ plus (3) $0.5 \mu \mathrm{M}$ OHHL, (4) $5 \mu \mathrm{M}$ OHHL, (5) $10 \mu \mathrm{M}$ compound 4, (6) $50 \mu \mathrm{M}$ compound 4, (7) $100 \mu \mathrm{M}$ compound 4, (8) $100 \mu \mathrm{M}$ compound 2 , or (9) $100 \mu \mathrm{M}$ compound 8. Bar 2 represents $E$. coli(pGroESL) treated with $0.5 \mu \mathrm{M}\left[{ }^{3} \mathrm{H}\right] \mathrm{OHHL}$ alone. All treatments were performed in triplicate and error bars represent standard deviation.

pound 3 and compounds 1,2 and 8 in that order. Additionally, the relief of inhibition produced by adding more OHHL to the culture medium for each compound is shown. Competitive relief of inhibition was partial, with the effect of the strongest inhibitors being the most difficult to antagonize with OHHL. Based on potency, compound 4 was selected as the most appropriate halogenated furanone with which to perform the studies reported in this paper.

\section{Displacement of $\left[{ }^{3} \mathrm{H}\right] \mathrm{OHHL}$ from LuxR by furanones}

It has previously been shown that $\left[{ }^{3} \mathrm{H}\right] \mathrm{OHHL}$ binds to E. coli cells overproducing LuxR (Adar \& Ulitzur, 1993; Hanzelka \& Greenberg, 1995). This is the strongest evidence supporting an interaction between OHHL and LuxR. The current model of inhibition by furanones suggests that the algal metabolites act by disrupting this interaction (Givskov et al., 1996). To test this directly we first added $\left[{ }^{3} \mathrm{H}\right] \mathrm{OHHL}$ to a final concentration of $0.5 \mu \mathrm{M}$ to cultures of E. coli XL-1 Blue(pGroESL) and E. coli XL-1 Blue(pHK724, pGroESL). pGroESL encodes chaperone proteins which assist in the folding of a functional LuxR (Hanzelka \& Greenberg, 1995). In preliminary binding experiments three different concentrations of $\left[{ }^{3} \mathrm{H}\right] \mathrm{OHHL}(0 \cdot 04,0 \cdot 2$ and $2 \mu \mathrm{M})$ were tested. In support of previously published results, significantly more $\left[{ }^{3} \mathrm{H}\right] \mathrm{OHHL}$ bound to $E$. coli cells overproducing LuxR than to wild-type cells (Fig. 3). At $0.2 \mu \mathrm{M}$ $\left[{ }^{3} \mathrm{H}\right] \mathrm{OHHL}$ the cells bound only $16 \%$ of what was bound when $2 \mu \mathrm{M}$ was used (data not shown). This suggested that $0 \cdot 2 \mu \mathrm{M}\left[{ }^{3} \mathrm{H}\right] \mathrm{OHHL}$ did not saturate the LuxR overproduction system. Based on this, $0.5 \mu \mathrm{M}$ $\left[{ }^{3} \mathrm{H}\right] \mathrm{OHHL}$ was considered a close to saturating concentration to employ in the study. Compound 4 , the most inhibitory furanone in the luminescent assay, was then tested at different concentrations $(10,50$ and $100 \mu \mathrm{M})$ for its ability to displace $\left[{ }^{3} \mathrm{H}\right] \mathrm{OHHL}$ from $E$. coli(pHK724, pGroESL) cultures. Fig. 3 shows that compound 4 displaces $\left[{ }^{3} \mathrm{H}\right] \mathrm{OHHL}$ from $E$. coli cells overproducing LuxR in a concentration-dependent manner. Similarly, compound 2, which has been used predominantly in previous studies (Givskov et al., 1996), was tested at $100 \mu \mathrm{M}$ for its effect on displacement. Compound 2 also reduced binding of $\left[{ }^{3} \mathrm{H}\right] \mathrm{OHHL}$ to $E$. coli(pHK724, pGroESL) cultures, but to a lesser extent than compound 4 , corresponding to its lower activity in the luminescent assay. Finally we tested the ability of compound 8 , which is much less active in the bioluminescent phenotypic assay than compound 2 or compound 4 (Fig. 2), to displace $\left[{ }^{3} \mathrm{H}\right] \mathrm{OHHL}$ from $E$. coli(pHK724, pGroESL) cultures. Fig. 3 shows that the effect of $100 \mu \mathrm{M}$ compound 8 on the OHHL-LuxR interaction is much less than for the other furanones.

The ability of unlabelled OHHL to displace $\left[{ }^{3} \mathrm{H}\right] \mathrm{OHHL}$ from LuxR-overproducing cells is also shown in Fig. 3. This allows for a comparison of the displacing efficacy between OHHL and furanones. The results suggest that compound 4 is approximately 25 times less efficient than OHHL at displacing $\left[{ }^{3} \mathrm{H}\right] \mathrm{OHHL}$ from LuxR-overproducing E. coli cells.

\section{Furanones have limited impact on global protein production: 2-D PAGE analysis}

2-D PAGE was employed to find out if compound 4 has any significant non-target effects on protein synthesis in the bioluminescent monitor strain E. coli(pSB403). We regarded E. coli, which has no AHL signalling system of its own and a comprehensive proteome database, as the most appropriate organism in which to assess nonAHL-related effects of furanones. Three samples of cells labelled with $\left[{ }^{35} \mathrm{~S}\right]$ methionine were prepared and analysed: (i) E. coli(pSB403) untreated (data not shown); (ii) E. coli(pSB403) plus $0.5 \mu \mathrm{M}$ OHHL (Fig. 4a); (iii) E. coli(pSB403) plus $0.5 \mu \mathrm{M}$ OHHL and $50 \mu \mathrm{M}$ compound 4 (Fig. 4b). It was possible to compare approximately 400 protein spots based on whether they could be matched positionally and did not vary in intensity by more than $20 \%$ of the mean value on triplicate gels. A greater than twofold change in spot density was considered as a difference in protein expression.

The addition of OHHL to E. coli(pSB403) culture medium upregulated only three of the proteins resolved in the analysis (Fig. 4). According to their apparent pI and $M_{\mathrm{r}}$ these three proteins are likely to be LuxA, LuxB and LuxD (labelled 1, 2 and 3, respectively, in Fig. 4) from the $X$. luminescens lux cassette encoded on pSB403 (Johnston et al., 1990; Cochrum et al., 1991). Addition of compound 4 to the culture medium downregulated the expression of these three proteins (Fig. 4). There were an additional nine changes (three downregulated 

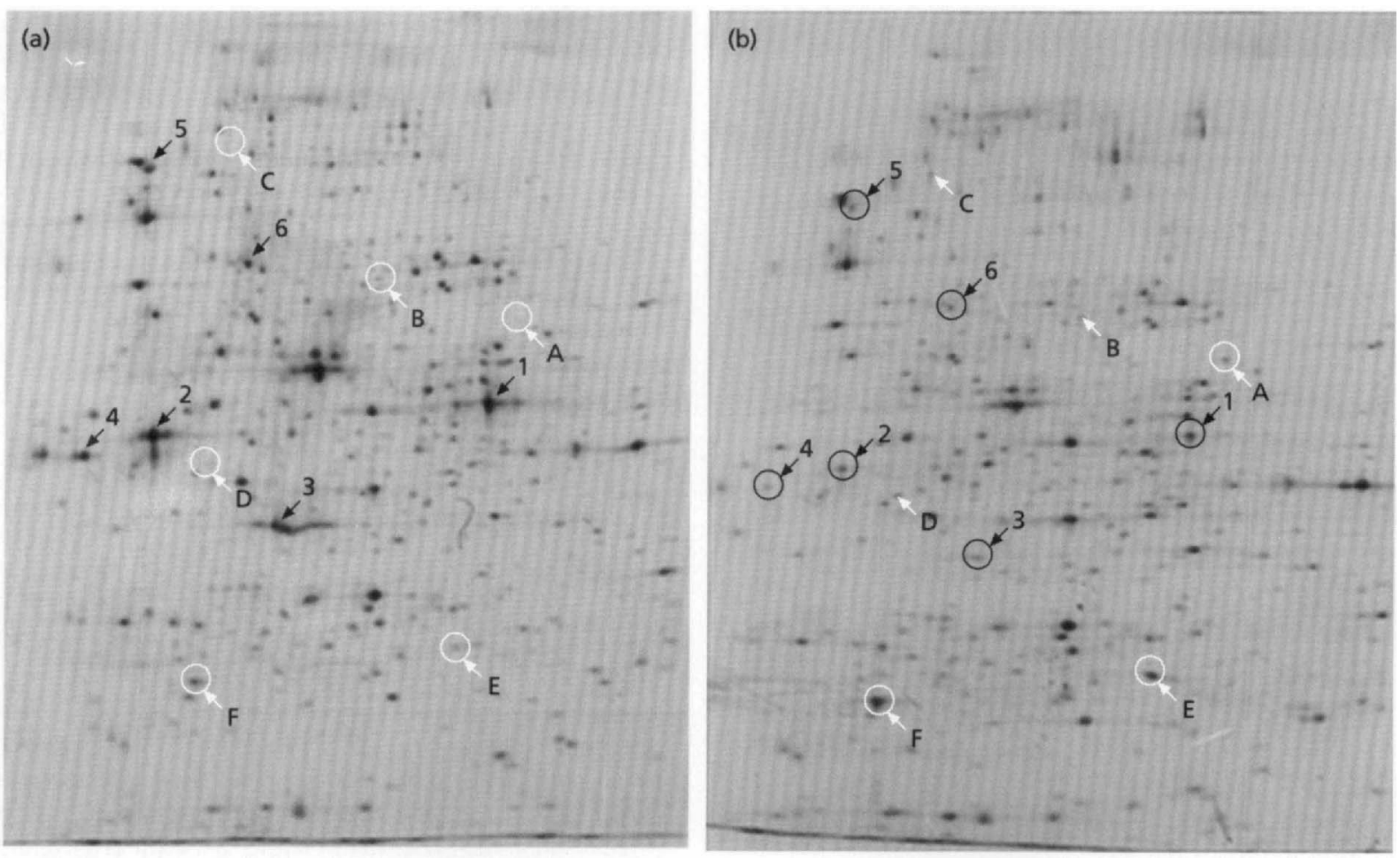

Fig. 4. 2-D PAGE gel of $E$. coli(pSB403) treated with $0.5 \mu \mathrm{M}$ OHHL (a) and $0.5 \mu \mathrm{M}$ OHHL plus $50 \mu \mathrm{M}$ compound 4 (b) prior to $\left[{ }^{35} S\right]$ methionine pulse-labelling. Six proteins (1-6) are downregulated by $50 \mu \mathrm{M}$ compound 4 (black arrows), including those three (1-3) upregulated by $0.5 \mu \mathrm{M} \mathrm{OHHL}$. An additional six proteins (A-F) are upregulated by $50 \mu \mathrm{M}$ compound 4 (white arrows). Spots with a twofold density shift were considered to have altered expression.

Table 1. Putative identities of proteins with altered expression in the presence of compound 4

\begin{tabular}{|c|c|c|c|c|}
\hline Spot & Coordinates* & $\mathbf{A}-\mathbf{N} \dagger$ & Protein & Gene \\
\hline \multicolumn{5}{|c|}{ Downregulated } \\
\hline 1 & Not found & - & LuxA & $\operatorname{lu} x A$ \\
\hline 2 & Not found & - & LuxB & $\operatorname{lu} x B$ \\
\hline 3 & Not found & - & LuxD & $\operatorname{lux} D$ \\
\hline 4 & 106,108 & B036.0 & $\mathrm{OmpF}$ & $o m p F$ \\
\hline 5 & $97,146 \cdot 5$ & B066.0 & DnaK/Hsp70 & $d n a K$ \\
\hline 6 & $76 \cdot 5,134 \cdot 5$ & D050.0 & Glutamate-ammonia ligase & $g \ln A$ \\
\hline \multicolumn{5}{|c|}{ Upregulated } \\
\hline A & Not found & - & - & - \\
\hline B & $55 \cdot 5,130 \cdot 5$ & F048.8 & Glucose-6-phosphate dehydrogenase & $z w f$ \\
\hline $\mathrm{C}$ & $79 \cdot 5,149 \cdot 5$ & $\mathrm{C} 075$ & Not known & - \\
\hline $\mathrm{D}$ & $83 \cdot 5,106 \cdot 5$ & $\mathrm{C} 037.5$ & Not known & - \\
\hline E & $40,82 \cdot 5$ & G025.9 & Not known & - \\
\hline $\mathrm{F}$ & $85 \cdot 5,68 \cdot 5$ & B020.9 & Alkylhydroperoxide reductase & $a b p C$ \\
\hline
\end{tabular}

* $x$, $y$ coordinates in $E$. coli $\mathrm{K}-12$ gene-protein database.

† Alpha-numeric ID of protein spots in E. coli K-12 gene-protein database.

and six upregulated) in protein expression in response to compound 4 . The identity of some of these proteins, as predicted by comparison with the E. coli $\mathrm{K}-12$ database (VanBogelen et al., 1996) are presented in Table 1. One spot (A) could not be associated with any proteins in the database and the identities of three of the remaining eight proteins are currently not known. Compound 4 $(50 \mu \mathrm{M})$ downregulated production of the outer-mem- 

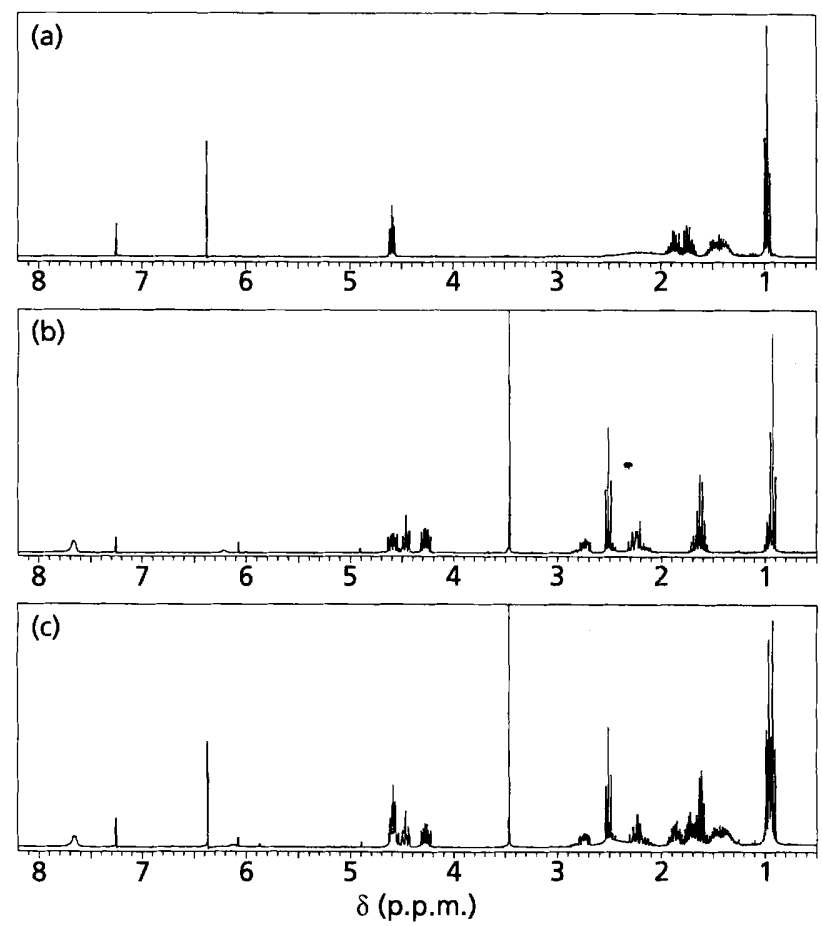

Fig. 5. 'H NMR spectra of (a) compound 4, (b) OHHL and (c) a mixture of compound 4 and $\mathrm{OHHL}$ in $\mathrm{CDCl}_{3}$ incubated at room temperature for $24 \mathrm{~h}$. Characteristic spectra for both compounds $(a, b)$ observed individually are present in the mixture (c), indicating no reaction between the two compounds.

brane porin protein $\mathrm{OmpF}$, the chaperone DnaK and the nitrogen-limitation-induced glutamate-ammonia ligase. The same treatment upregulated production of glucose6-phosphate dehydrogenase (zwf gene product), which acts in the oxidative branch of the pentose-phosphate pathway, and alkylhydroperoxide reductase $(a h p C$ gene product), which responds to oxidative stress. The significance of these particular changes is considered in the Discussion. These minor changes in non-AHLrelated proteome expression and the significant changes in expression of the putative LuxA, LuxB and LuxD proteins indicated that halogenated furanones do not disrupt normal metabolic activity and that the effect on the expression of the target genes is specific.

\section{Furanones and $\mathrm{OHHL}$ do not react in vitro}

The inhibition of AHL-regulated phenotypes by furanones could potentially be explained by a covalent interaction between the two molecules. To test this hypothesis compound 4 was mixed in vitro with OHHL in a polar (DMSO) or non-polar (chloroform) medium in the presence or absence of an E. coli culture. The polarity of the solvent was varied to see if this was an important factor in a hypothetical interaction. The polarity of DMSO is similar to that of water and is thus more ecologically relevant. The E. coli culture was included to ascertain whether its presence facilitated a reaction between the compounds. After 2, 8, 24 or $48 \mathrm{~h}$ no changes in the proton chemical shifts for either OHHL or compound 4 , as determined by ${ }^{1} \mathrm{H}$ NMR spectroscopy, were observed in any of the four treatments, indicating no reaction between the two compounds. Fig. 5 shows the ${ }^{1} \mathrm{H}$ NMR spectra for compound 4 and OHHL individually and mixed in chloroform after $24 \mathrm{~h}$. Similarly, migration of the mixture on TLC plates indicated the presence of OHHL and compound 4 only (data not shown).

\section{DISCUSSION}

The attention currently being paid to chemical signalling in bacterial ecology is unprecedented. Signals are employed by and against a wide cross-section of the microbial community (Kleerebezem et al., 1997; Fuqua et al., 1996; Dunny et al., 1995; Guangyong et al., 1997). Out of the diverse range of signalling systems, AHLmediated gene expression is unparalleled in its predominant regulation of colonization phenotypes, often of higher organisms. Given this and the diversity of biologically active secondary metabolites in marine and terrestrial eukaryotes, it would be expected that these higher organisms have evolved chemical inhibitors of AHL-mediated gene expression. We have hypothesized that furanones from the red alga $D$. pulchra function in just this fashion.

To date, evidence for this hypothesis, besides the structural similarities between furanones and AHLs, stems from the furanone-imposed inhibition of colonization phenotypes of marine bacteria (Maximilien et al., 1998) and AHL-dependent phenotypes of assay strains (Givskov et al., 1996). These inhibitory effects occur at ecologically realistic concentrations of the algal metabolites, as based on epifluorescence microscopy (furanones occur in specialized gland cells at the plant surface) and direct measurement of surface concentrations of furanones (de Nys et al., 1998). The ecological consequences of furanones at the surface of D. pulchra are lower levels of bacteria on parts of the plant that have high levels of furanones and lower levels of bacteria on D. pulchra in comparison to other algae in the same environment (Maximilien et al., 1998).

To confirm our hypothesis that $D$. pulchra inhibits bacteria by interfering with AHL-mediated gene expression, we need to demonstrate (i) the mechanism of action of furanones in AHL systems and (ii) that furanones inhibit AHL systems in bacteria that co-occur with D. pulchra. Genetic characterization of AHL systems in these marine bacteria is in progress (unpublished data). Here we focus on identifying the mechanism of action of furanones in AHL systems. The $V$. fischeri AHL system was preferred for this study owing to its thorough characterization and the marine origin of the organism.

To test directly whether halogenated furanones displace AHL from the putative binding site on the regulatory 
protein we employed the LuxR overproducer $E$. coli(pHK724, pGroESL) and $\left[{ }^{3} \mathrm{H}\right] \mathrm{OHHL}$. Compound 4 was shown to be capable of such displacement, with compound 2 and compound 8 showing decreasing activity. The different activities in the displacement assay correspond to the inhibitory strengths that the furanones exhibited in the luminescence assay. These findings, in conjunction with the partial relief of furanone-imposed inhibition of bioluminescence by OHHL (Fig. 2), support a model in which furanones bind or disfigure the OHHL-binding site of LuxR.

It may be questioned whether halogenated furanones exert their effect on non-essential phenotypes such as swarming and bioluminescence by a non-specific disruption of primary metabolic function. Monitoring the optical density of cultures as a measure of growth in the presence of the compounds suggests this is not the case (Givskov et al., 1996); however it can be argued that the disruption may be too subtle to affect cell division and thus may not be detected. Analysis of protein production by 2-D PAGE provides definitive evidence that furanones, at the concentrations employed, have limited non-AHL-related effects. Of approximately 400 proteins resolved only 12 were affected by the addition of $50 \mu \mathrm{M}$ compound 4 . Of these 12 , three are upregulated by OHHL, suggesting they are $l u x$ proteins and are thus expected to show shifts in expression. The predicted $\mathrm{pI}$ and $M_{r}$ of these protein spots are in accordance with this.

Attempts to identify the remaining changes by comparison with the E. coli K-12 gene-protein database revealed the upregulation of glucose-6-phosphate dehydrogenase (zwf gene product) and alkylhydroperoxide reductase $(a h p C$ gene product). These gene products belong to two separate regulons (SoxRS and OxyR, respectively) which are active in the presence of oxidative stress. Each operon contains approximately 40 proteins. Analysis of the data presented in Fig. 4 revealed that no changes in expression of the remaining proteins in these regulons occurred. This suggests that the upregulation of $z w f$ and $a h p C$ does not represent an induction of oxidative stress responses in the presence of $50 \mu \mathrm{M}$ compound 4 . The significance of the downregulation of the $d n a K$ and $g \ln A$ gene products is not currently understood. The downregulation of $\mathrm{OmpF}$, in light of the enhanced synthesis of two of the oxidative stress gene products, might in principle be explained by increased expression of the SoxR-dependent micF gene, the product of which inhibits synthesis of OmpF. However, the lack of induction of all but two of the visualized protein spots in the oxidative stress regulons makes this explanation less plausible. Upregulation of the unidentified proteins designated with alpha-numeric IDs C075, C037.5 and G025.9 is not associated with the oxidative stress regulons (VanBogelen et al., 1996).

The limited effect of OHHL on expression of proteins in E. coli(pSB403) is a reminder of the non-native background in which the bioluminescence assay is performed. OHHL does not perform the function of signalling molecules contained in E. coli (Garcia-Lara et al., 1996).

Given the similarities in their structures, the mode of action by which furanones interfere with OHHL-driven bioluminescence is most likely to involve the AHLbinding site. However, it is possible that the observed effects of the halogenated furanones on AHL systems could be explained by a direct chemical interaction between the algal metabolites and the bacterial signals which disables the AHL's ability to activate a LuxR homologue. For example, the hydroxyl group of the most inhibitory furanone (compound 4) might have undergone a transacylation reaction with the keto or amide function of OHHL. Assessment of a mixture of compound 4 and OHHL by ${ }^{1} \mathrm{H}$ NMR and TLC revealed the presence of the individual compounds only, indicating that there is no in vitro reaction between the two. This was observed in both a non-polar and polar medium, and in both the presence and absence of an $E$. coli culture, suggesting that no reaction would take place in situ in the natural aqueous environment.

The use of six unique furanone structures in the bioluminescence assay provided the opportunity to assign functional importance to particular moieties. Specifically, the hydroxy group at the $\mathrm{C}^{\prime}$ position (see compound 4 in Fig. 1) confers a higher inhibitory activity than the acetoxy group (see compound 3 ), which in turn confers higher activity than a hydrogen atom (see compound 2) at this position. Additionally, this hydroxy group confers an irreversibility of inhibition to the furanone that the acetoxy group does not. Finally, the presence of a bromine atom extending from the carbon 4 position on the furan ring (compare $\mathrm{C} 1$ to $\mathrm{C} 8$ ) increases the biological activity of the structure. Such clear differences in activity associated with these minor changes in chemical structure have prompted a more comprehensive structure/function investigation which will be the focus of future studies.

This study adds crucial supportive evidence to the contention that the eukaryote $D$. pulchra controls bacterial colonization of its surface by producing metabolites which specifically interfere with AHLdependent gene transcription at the level of the LuxRlike regulatory protein. In an evolutionary context, the discovery of naturally produced AHL antagonists by a benthic marine macroalga suggests that other organisms, also subject to AHL-mediated colonization by Gram-negative bacteria, may also possess mechanisms for interfering with bacterial communication.

\section{ACKNOWLEDGEMENTS}

This work was supported by the Australian Research Council (ARC) and the Centre for Marine Biofouling and BioInnovation. Rocky de Nys is funded by an ARC research fellowship. Input from Lone Gram and Lachlan Harris in the preparation of this manuscript was greatly appreciated. We 
are indebted to William Lao and Anthony Manny for the synthetic chemistry. We are also grateful to Brian Hanzelka for supplying the LuxR overproduction strains. Thanks to Mike Winson for the gift of the luminescent monitor plasmid pSB403.

\section{REFERENCES}

Adar, Y. \& Ulitzur, S. (1993). GroESL proteins facilitate binding of externally added inducer by LuxR protein-containing Escherichia coli cells. J Biolumin Chemilumin 8, 261-266.

Bainton, N., Bycroft, B., Chhabra, S. \& 8 other authors (1992). A general role for the lux autoinducer in bacterial cell signalling: control of antibiotic biosynthesis in Erwinia. Gene 116, 87-91.

Cochrum, L., Hruska, S., Rucker, E. \& Johnston, S. (1991). The nucleotide sequence of the luxD gene of Xenorhabdus luminescens. Nucleic Acids Res 18, 5570.

Dunlap, P. (1989). Regulation of luminescence by cyclic AMP in cya-like and crp-like mutants of Vibrio fischeri.J Bacteriol 171, 1199-1202.

Dunny, P., Leonard, B. \& Hedberg, P. (1995). Pheremone-inducible conjugation in Enterococcus faecalis: interbacterial and hostparasite chemical communication. J Bacteriol 177, 871-876.

Eberhard, A., Widrig, C., McBath, P. \& Schineller, J. (1986). Analogues of the autoinducer of bioluminescence in Vibrio fischeri. Arch Microbiol 146, 35-40.

Eberl, L., Winson, M., Sternberg, C. \& 7 other authors (1996). Involvement of $\mathrm{N}$-acyl-L-homoserine lactone autoinducers in control of multicellular behaviour of Serratia liquefaciens. $\mathrm{Mol}$ Microbiol 20, 127-136.

Fuqua, C. \& Winans, S. (1994). A LuxR-LuxI type regulatory system activates Agrobacterium Ti plasmid conjugal transfer in the presence of a plant tumour metabolite. J Bacteriol 176, 2796-2806.

Fuqua, C., Burbea, M. \& Winans, S. (1995). Activity of the Agrobacterium $\mathrm{Ti}$ plasmid conjugal transfer regulator $\mathrm{TraR}$ is inhibited by the product of the traM gene. J Bacteriol 177, 1367-1373.

Fuqua, C., Winans, S. \& Greenberg, P. (1996). Census and consensus in bacterial ecosystems: the LuxR-LuxI family of quorum-sensing transcriptional regulators. Annu Rev Microbiol 50, 727-751.

Garcia-Lara, J., Shang, L. \& Rothfield, L. (1996). An extracellular factor regulates expression of $s d i A$, a transcriptional activator of cell division genes in Escherichia coli. J Bacteriol 178, 2742-2748.

Givskov, M., de Nys, R., Manefield, M., Gram, L., Maximilien, R., Eberl, L., Molin, S., Steinberg, P. \& Kjelleberg, S. (1996). Eukaryotic interference with homoserine lactone-mediated prokaryotic signalling. J Bacteriol 178, 6618-6622.

Gram, L., de Nys, R., Maximilien, R., Givskov, M., Steinberg, P. \& Kjelleberg, S. (1996). Inhibitory effects of secondary metabolites from the red alga Delisea pulchra on swarming motility of Proteus mirabilis. Appl Environ Microbiol 62, $4284-4287$.

Guangyong, J., Beavis, R. \& Novick, R. (1997). Bacterial interference caused by autoinducing peptide variants. Science $\mathbf{2 7 6}$, 2027-2030.

Hanzelka, B. \& Greenberg, P. (1995). Evidence that the N-terminal region of the Vibrio fischeri LuxR protein constitutes an autoinducer-binding domain. J Bacteriol 177, 815-817.
Johnston, T., Rucker, E., Cochrum, L., Hruska, K. \& Vandegrift, V. (1990). The nucleotide sequence of the $\operatorname{lu} x A$ and $\operatorname{lu} x B$ genes of Xenorhabdus luminescens and a comparison of the amino acid sequences of luciferases from four species of bioluminescent bacteria. Biochem Biophys Res Commun 170, 407-415.

Kaplan, H., Eberhard, A., Widrig, C. \& Greenberg, P. (1985). Synthesis of $\mathrm{N}$-[3-oxo- $\left(4,5-{ }^{3} \mathrm{H}_{2}\right)$-hexanoyl] homoserine lactone: biologically active tritium-labelled Vibrio fischeri autoinducer. $J$ Label Compd Radiopharm 22, 387-395.

Kjelleberg, S., Steinberg, P., Givskov, M., Gram, L., Manefield, M. \& de Nys, R. (1997). Do marine natural products interfere with prokaryotic AHL regulatory systems? Aquat Microb Ecol 13, 85-93.

Kleerebezem, M., Quadri, L. E., Kuipers, O. P. \& de Vos, W. M. (1997). Quorum sensing by peptide pheromones and twocomponent signal transduction systems in Gram-positive bacteria. Mol Microbiol 24, 895-904.

Maniatis, T., Fritsch, E. F. \& Sambrook, J. (1982). Molecular Cloning: a Laboratory Manual. Cold Spring Harbor, NY : Cold Spring Harbor Laboratory.

Manny, A., Kjelleberg, S., Kumar, N., de Nys, R., Read, R. \& Steinberg, P. (1997). Reinvestigation of the sulfuric acid-catalysed cyclisation of brominated 2-alkyllevulinic acids to 3-alkyl-5methylene-2(5H)-furanones. Tetrabedron 53, 15813-15826.

Maximilien, R. (1996). Inhibition of bacteria by seaweed secondary metabolites. Honours thesis, University of New South Wales, Australia.

Maximilien, R., de Nys, R., Holmstrom, C., Gram, L., Givskov, M. Crass, K., Kjelleberg, K. \& Steinberg, P. (1998). Chemical mediation of bacterial surface colonisation by secondary metabolites of the red alga Delisea pulchra. Aquat Microb Ecol 15, 233-246.

de Nys, R., Wright, A., Konig, M. \& Sticher, O. (1993). New halogenated furanones from the marine alga Delisea pulchra (cf. fimbriata). Tetrahedron 49, 11213-11220.

de Nys, R., Steinberg, P., Willemsen, P., Dworjanyn, S., Gabelish, C. \& King, R. (1995). Broad spectrum effects of secondary metabolites from the red alga Delisea pulchra in antifouling assays. Biofouling 8, 259-271.

de Nys, R., Dworjanyn, S. \& Steinberg, P. (1998). A new method for determining surface concentrations of marine natural products on seaweeds. Mar Ecol Prog Ser 162, 79-87.

O'Farrell, P. H. (1975). High resolution two-dimensional electrophoresis of proteins. J Biol Chem 250, 4007-4021.

Pearson, J., Pesci, E. \& Iglewski, B. (1997). Roles of Pseudomonas aeruginosa las and $r b l$ quorum sensing systems in control of elastase and rhamnolipid biosynthesis genes. J Bacteriol 179, $5756-5767$.

Pirhonen, M., Flego, D., Heikinheimo, R. \& Palva, E. (1993). A small diffusible signal molecule is responsible for the global control of virulence and exoenzyme production in the plant pathogen Erwinia carotovora. EMBO J 12, 2467-2476.

Sitnikov, D., Schinellar, J. \& Baldwin, T. (1995). Transcriptional regulation of bioluminescence genes from Vibrio fischeri. Mol Microbiol 17, 801-812.

Steinberg, P. \& van Altena, I. (1992). Tolerance of marine invertebrate herbivores to brown algal phlorotannins in temperate Australasia. Ecol Monogr 62, 189-222.

Swift, S., Throup, J., Williams, P., Salmond, G. \& Stewart, G. (1996). Quorum sensing: a population-density component in the 
determination of bacterial phenotype. Trends Biochem Sci 21, 214-219.

Ulitzur, S., Matin, A., Fraley, C. \& Meighan, E. (1997). H-NS protein represses transcription of the lux systems of Vibrio fischeri and other luminous bacteria cloned into Escherichia coli. Curr Microbiol 35, 336-342.

Van Bogelen, R., Abshire, K., Pertsemilidis, A., Clark, R. L. \& Neidhart, F. (1996). Gene-protein database of Escherichia coli K12, edition 6. In Escherichia coli and Salmonella, Cellular and Molecular Biology, 2nd edn, pp. 2067-2117. Edited by F. C.
Neidhart and others. Washington, DC: American Society for Microbiology.

Winson, M. K., Swift, S., Fish, L., Throup, J. P., Jorgensen, F., Chhabra, S. R., Bycroft, B. W., Williams, P. \& Stewart, G. S. A. B. (1998). Construction and analysis of $\operatorname{lu} x C D A B E$-based plasmid sensors for investigating $\mathrm{N}$-acyl homoserine lactone-mediated quorum sensing. FEMS Microbiol Lett 163, 185-192.

Received 22 September 1998; revised 6 November 1998; accepted 13 November 1998. 